\title{
CORRECTION
}

\section{Correction to: The Boldt scandal still in need of action: the example of colloids 10 years after initial suspicion of fraud}

\author{
Christian J. Wiedermann ${ }^{{ }^{*}}$ and Michael Joannidis ${ }^{2}$
}

(C) 2020 The Author(s)

\section{Correction to: Intensive Care Med (2018) 44:1735-1737} https://doi.org/10.1007/s00134-018-5289-3

The article "The Boldt scandal still in need of action: the example of colloids 10 years after initial suspicion of fraud", written by Christian J. Wiedermann and Michael Joannidis, was originally published Online First without Open Access. After publication in volume 44, issue 10 , page $1735-1737$ the author decided to opt for Open Choice and to make the article an Open Access publication. Therefore, the copyright of the article has been changed to (c) The Author(s) 2018 and the article is forthwith distributed under the terms of the Creative Commons Attribution NonCommercial 4.0 International License, which permits any non-commercial use, sharing, adaptation, distribution and reproduction in any medium or format, as long as you give appropriate credit to the original author(s) and the source, provide a link to the Creative Commons licence, and indicate if changes were made. The images or other third party material in this article are included in the article's Creative Commons licence, unless indicated otherwise in a credit line to the material. If material is not included in the article's Creative Commons licence and your intended use is not permitted by statutory regulation or exceeds the permitted use, you will need to obtain permission directly from the copyright holder. To view a copy of this licence, visit https://creativecommons.org/licenses/by-nc/4.0/.

The original version of this article was revised due to a retrospective Open Access order.

\section{Author details \\ ${ }^{1}$ UMIT-University of Health Sciences, Medical Informatics and Technology, Eduard-Wallnöfer-Platz 1, 6060 Hall in Tyrol, Austria. ${ }^{2}$ Division of Medical Intensive Care and Emergency Medicine, Department of Internal Medicine I, Medical University of Innsbruck, Innsbruck, Austria.}

\section{Open Access}

This article is licensed under a Creative Commons Attribution-NonCommercial 4.0 International License, which permits any non-commercial use, sharing, adaptation, distribution and reproduction in any medium or format, as long as you give appropriate credit to the original author(s) and the source, provide a link to the Creative Commons licence, and indicate if changes were made. The images or other third party material in this article are included in the article's Creative Commons licence, unless indicated otherwise in a credit line to the material. If material is not included in the article's Creative Commons licence and your intended use is not permitted by statutory regulation or exceeds the permitted use, you will need to obtain permission directly from the copyright holder. To view a copy of this licence, visit http://creativecommons.org/licen ses/by-nc/4.0/.

\section{Publisher's Note}

Springer Nature remains neutral with regard to jurisdictional claims in published maps and institutional affiliations.

Published online: 13 October 2020

*Correspondence: christian.wiedermann@ext.umit.at

${ }^{1}$ UMIT-University of Health Sciences, Medical Informatics and Technology,

Eduard-Wallnöfer-Platz 1, 6060 Hall in Tyrol, Austria

Full author information is available at the end of the article

\section{实

